\title{
Experimental Investigation of Bolted Angle Joints for Cold-formed Steel with Double Channel Sections
}

\author{
[Cher Siang Tan, Mahmood Md Tahir, Mustapha Muhammad Lawan ]
}

\begin{abstract}
The application of cold-formed steel in light steel framing design can serve as an alternative for industrialized building system, by extending steelwork construction into residential housing. There is a lack of in-depth study on the joints behaviour in cold-formed steel frames, particularly the beam-tocolumn connection. This paper presents isolated joint test on three types of joints using bolts and steel angles, namely webcleats, top-seat flange-cleats and combined flange-web-cleats connections. Six specimens with different joint configuration and thickness of angle were tested. The experimental setup, procedures and failure modes of the joints are discussed in detail. The comparison revealed that by increasing the thickness of angle from $2 \mathrm{~mm}$ to $6 \mathrm{~mm}$, the strength of joint's moment resistance increased in the range of 1.80 to 2.28 . The ratio of difference for rotational stiffness increased in the range of 1.27 to 2.06.
\end{abstract}

Keywords - Cold-formed steel, double channel section, bolted joints, angle connection, partial strength, stiffness.

\section{Introduction}

Industrialized Building System (IBS) is one of the prefabricated building technologies that is being promoted diligently by CIDB Malaysia [1]. Having building manufacturing works transferred to the factory could reduce dependency on mass unskilled foreign labor, produce higher quality control building and increase productivity. At the same time IBS can reduce construction time and material wastage, keeping the construction site cleaner and free from rubble. The application of cold-formed steel in light steel framing design can become part of Industrialized Building System that optimizes economical and sustainable construction.

Cher Siang Tan

Faculty of Civil Engineering, Universiti Teknologi Malaysia (UTM) Malaysia

Mahmood Md Tahir

UTM Construction Research Centre, Universiti Teknologi Malaysia (UTM) Malaysia

Mustapha Muhammad Lawan

UTM Construction Research Centre, Universiti Teknologi Malaysia (UTM) Malaysia
The use of bolts and angles can eliminate the dependence on welding works in production of joints for steel structures,. The bolted connection can be formed into three types, namely web-cleat connection (WC), flange-cleat connection (FC) and combined flange-web-cleat connection (FWC) as shown in Fig. 1. Research has been carried out $[2,3]$ to study the strength and stiffness behaviour of angle connection in hotrolled steel structures. Little works have been done on angle connection for cold-formed steel structures. Chung and Lawson [4] studied the shear strength of single web-cleats (WC) for cold-formed steel channel sections. Tan et al. [5-7] reported experimental tests on various joint configurations for cold-formed steel beam-to-column connections. This paper covers on the investigation of bolted angle joints for coldformed steel frames built with $250 \mathrm{~mm}$ double channel sections.

In order to obtain the most realistic information on physical behaviour of steelwork joints, best practices utilize experimental tests performed on full-scaled structural frames [8]. The connections are known to strongly affect the overall response of a frame, and likewise, the frame behaviour may influence the mechanical properties of the connections. However, the incurred cost in performing tests on the whole frame is high, and the tests may demand huge and specific testing facilities. So, tests on isolated joints could be carried out with limited scope as mentioned.

The experimental design employed for the isolated tests in this study are cantilever arrangement. The moment resistance of the joints are developed by the load applied at the end of the cantilever beam. With respect to the external joints of a steel frame, the cantilever arrangement is relatively sufficient in producing expected results especially the moment-rotation characteristics. Many researchers have resorted to this type of arrangement in their studies, e.g. Bose and Hughes [9], Mottram and Zheng [2] and Prinz et al. [10]. For cold-formed steel connections, Markazi et al.[11], Chung and Lau [12] and Wong and Chung [13] also conducted series of isolated joint tests to determine the moment-rotation behaviour of their proposed connection methods.

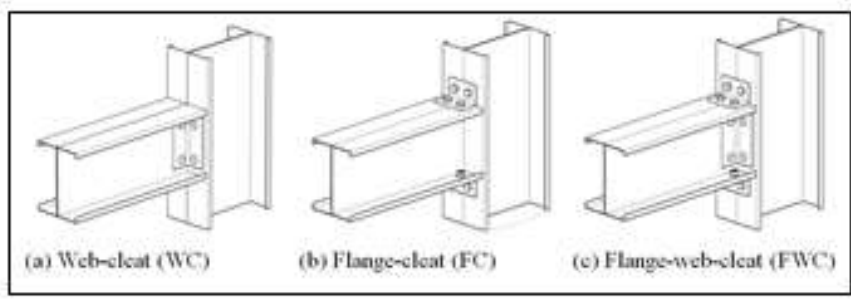

Figure 1. Bolted angle joints for cold-formed steel frame 
Proc. of the Third Intl. Conf. Advances in Civil, Structural and Mechanical Engineering- CSM 2015 Copyright (C) Institute of Research Engineers and Doctors, USA .All rights reserved.

ISBN: 978-1-63248-062-0 doi: 10.15224/ 978-1-63248-062-0-30

\section{Methodology}

Cold-formed steel lipped channel sections manufactured by Kemuning Structures S/B were used as beam and column members of steel frame. The grade of steel is $350 \mathrm{~N} / \mathrm{mm} 2$ and the thickness of each channel section was $2 \mathrm{~mm}$. The depth of the sections was $250 \mathrm{~mm}$. All specimens were cut into desired length and bundled up to transport to the structural laboratory of Universiti Teknologi Malaysia. Two lipped channel sections were placed back-to-back to form an I-section, with intermediate fasteners at $500 \mathrm{~mm}$ for beam sections of 1.5meter length, and $1000 \mathrm{~mm}$ for column sections of 3-meter length. The beam and column are named as Double Channel sections, i.e. DC250.

Fasteners used in the study are non-preloaded bolts M12 Grade 8.8 with two washers. The bolt holes were standardized to $13 \mathrm{~mm}$ toprevent abrupt deformation due to wide holespaces between the steel members [14]. The connections were formed by using $2 \mathrm{~mm}$ and $6 \mathrm{~mm}$ angles. The experimental test specimens are summarized in Table 1. Tensile test of steel-coupon cut from the specimens were tested and recorded [15] to validate the actual yield strength of steel and satisfy the designed yield strength.

A total of six tests were carried out in the Magnus Frame as shown in Fig. 2. The out-of-plane movement of the test specimens was restrained by bracing system. The load was applied using hydraulic jack and recorded by $100 \mathrm{kN}$ load cell. Six displacement transducers (DT) namely DT1 to DT6 were placed on the beam and column members to record deformation. One inclinometer was placed at the centre of each column and beam section, near the connection to record the rotation of the respective structural members. The data acquisition layout is given in Fig. 2. The data from load cell and LVDT were directly recorded in the computer via data logger, while reading from inclinometers was manually recorded throughout the test program.

The loading was applied with an increment of $0.2 \mathrm{kN}$. Through inspection, when an estimated $25 \%$ of the analytical designed load was reached, the specimens were unloaded and then re-loaded after the reading was initialized to zero. This procedure was adapted so as to enable the specimens reach an equilibrium stage. The specimen was further loaded until a significantly large deflection of the beam was observed. At that stage the increments of applied load was controlled by the deflection instead of the load. A deflection of $5 \mathrm{~mm}$ was adopted as a suitable increment of the stage. The procedure continued until the specimen had reached its failure condition. The 'failure' condition was deemed to have been reached when any of the situations mentioned below occurred:

i. An abrupt and significantly large reduction in the applied load being attained.

ii. An abrupt and significantly large increment in the deflection of the beam was attained with significant deformation of the connections. iii. Excessive deflection of the beam, which was over $150 \mathrm{~mm}$ or reaching the DT's limit.

It was estimated that more than one failure mode may occur before the joint reached its limit. Thus the failure mode was being carefully observed along the test program, so that the sequence of the failure modes could be systematically recorded down and compared to the obtained data.

TABLE I. DETAILS OF LABORATORY SPECIMENS

\begin{tabular}{|c|c|c|c|c|}
\hline $\begin{array}{l}\text { Test } \\
\text { No }\end{array}$ & $\begin{array}{c}\text { Size of beam and } \\
\text { column }\end{array}$ & $\begin{array}{c}\text { Size of } \\
\text { web cleat }^{2}\end{array}$ & $\begin{array}{l}\text { Size of } \\
\text { flange } \\
\text { cleat }^{2}\end{array}$ & $\begin{array}{c}\text { No } \\
\text { of } \\
\text { Bolt } \\
\mathrm{s}^{\mathbf{3}}\end{array}$ \\
\hline 1 & \multirow{6}{*}{$\begin{array}{l}\text { DC200 } \\
\text { Depth, } D=250 \mathrm{~mm} \\
\text { Breadth, } B=77 \mathrm{~mm} \\
\text { Thickness, } t=2.0 \mathrm{~mm} \\
\text { Root radius, } r=2.5 \\
\mathrm{~mm}\end{array}$} & $\begin{array}{c}200 \times 60 \times 2 \\
-S 350\end{array}$ & & 6 \\
\hline 2 & & & $\begin{array}{c}100 \times 60 \times 2 \\
-S 350\end{array}$ & 8 \\
\hline 3 & & $\begin{array}{c}200 \times 60 \times 2 \\
-S 350\end{array}$ & $\begin{array}{c}100 \times 60 \times 2 \\
-S 350\end{array}$ & 14 \\
\hline 4 & & $\begin{array}{c}200 \times 60 \times 6 \\
-S 275\end{array}$ & & 6 \\
\hline 5 & & & $\begin{array}{c}100 \times 60 \times 6 \\
-S 275\end{array}$ & 8 \\
\hline 6 & & $\begin{array}{c}200 \times 60 \times 6 \\
-S 275\end{array}$ & $\begin{array}{c}100 \times 60 \times 6 \\
-S 275\end{array}$ & 14 \\
\hline \multicolumn{5}{|c|}{$\begin{array}{l}\text { Note: } \\
1 \text {. The dimension of beam and column are as per manufacturer's } \\
\text { specification. Design steel grade }=350 \mathrm{~N} / \mathrm{mm}^{2} \text {. } \\
\text { 2. Flange cleat and web cleat size label: length } \times \text { width } \times \text { thickness - } \\
\text { design strength. } \\
\text { 3. All bolts M12 Grade } 8.8 \text { with two washers. Bolt size } d_{\mathrm{b}}=12 \mathrm{~mm} \text {; } \\
\text { Diameter of bolt hole } d_{\mathrm{h}}=d_{\mathrm{b}}+1 \mathrm{~mm}=13 \mathrm{~mm} \text {. }\end{array}$} \\
\hline
\end{tabular}

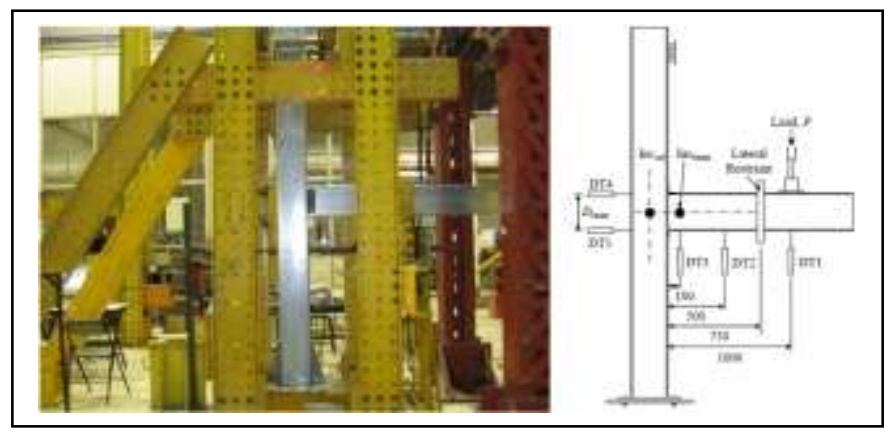

Figure 2. Bolted angle joints for cold-formed steel frame

\section{Results and Discussion}

All the isolated joint tests were conducted until failure, which occurred for a variety of reasons: yielding of anglecleats, yielding of column flange around the bolts and bending of column flange. All tests were stopped due to excessive deflection of beam over $150 \mathrm{~mm}$. The modes of failure are explained in detail, assisted by pictures.

The $2 \mathrm{~mm}$ cold-formed bracket double angle web-cleats (WC) in test 1 served as pin connection [4]. At early stage of 
Proc. of the Third Intl. Conf. Advances in Civil, Structural and Mechanical Engineering- CSM 2015 Copyright (C) Institute of Research Engineers and Doctors, USA .All rights reserved.

ISBN: 978-1-63248-062-0 doi: 10.15224/ 978-1-63248-062-0-30

the test progress, visible bending already occurred at the top part of the web-cleats. The web-cleats continue to tear-buckle widely. The bending of web-cleats caused large deflection in the connected beam. The test was stopped when DT1 record exceeded $150 \mathrm{~mm}$. There was no visible defect apparent in the bolts, beam and column section. In test 2 , the top-seat flangecleat (FC) started to tear out when the loading reached about 1 $\mathrm{kN}$. When the top-flange yielded till the bolted part, it caused large deformation and reduced the strength. The bended flange-cleat started to pull the bolts at the column flange, caused a slight increment of load capacity, but did not reduce the deflection. The tests had to be stopped due to excessive deflection. Combined flange-web-cleat (FWC) in test 3 increased the stiffness and strength of the connection compared to WC and FC. The combination of top-flange and double web-cleats minimized the bending of these brackets, which led to the reduction of beam's deflection. However, when the flange-cleat created greater yielding, flange-cleat and web-cleats started to pull the flange of the column, resulting in a slight increment of load capacity.

The $6 \mathrm{~mm}$ web-cleats were also designed as pin connection in test 4. But those thick web-cleats were stiffer than the column flange which caused the column flange to bend. The web-cleats continued to pull the column flange creating excessive deflection in the connected beam. The tests were stopped when deflection at DT1 recorded over $150 \mathrm{~mm}$. The web-cleat did not buckle and had no visible defect. In test 5 , top-seat flange-cleat (FC) also pulled the relatively thin, 2 $\mathrm{mm}$ column flange and beam flange. In comparison, the top angle-cleat of the cold-formed bracket did not yield. The yielding happened only at the connected flanges of beam and column. The FC connection developed large deformation, causing the bottom flange-cleat to compress the column flange which crushed the column. Combined flange-web-cleat (test 6) resulted in the highest strength and rotational stiffness when compared with to test 1 to test 5 . The stiff top flange-cleat and web-cleats pulled the column flange; while the bottom flangecleat pushed into the column flange, and the column flange was bent. The critical failure mode was noticed in the compression zone of column flange. High concentrated force from the bottom flange of beam pushed at the column flange, until the web part of column buckled. The buckling of column web marked the highest load applied, and loading started to decrease before the deflection at DT1 reached $150 \mathrm{~mm}$.

The effect of increasing thickness of angle-cleats from 2 $\mathrm{mm}$ to $6 \mathrm{~mm}$ was compared for three types of cleat connection, as depicted in Fig. 3. The quantified comparison is listed in Table 2. For comparison purposes, the moment of joints $\left(M_{\mathrm{J}-50}\right)$ was taken at the rotation of $50 \mathrm{mRad}$ [12-13], and stiffness $\left(S_{\mathrm{J}, \text { ini }}\right)$ measured at the initial stage. It was observed that by increasing the angle-cleat size from $2 \mathrm{~mm}$ to $6 \mathrm{~mm}$, the moment resistance increased in the range of 1.80 to 2.28. The ratio of difference for rotational stiffness increased in the range of 1.27 to 2.06 .
TABLE II. STRENGTH AND STIFFNESS BETWEEN 2 MM CLEATS AND 6 MM BOLTED ANGLE JOINTS

\begin{tabular}{|c|c|c|c|c|}
\hline \multirow[t]{2}{*}{ No } & \multirow[t]{2}{*}{ Connection type } & \multicolumn{3}{|c|}{ Comparison of $M_{\mathrm{J}-50}(\mathrm{kNm})$} \\
\hline & & $\begin{array}{l}2 \mathrm{~mm} \\
\text { cleat }\end{array}$ & $\begin{array}{l}6 \mathrm{~mm} \\
\text { cleat }\end{array}$ & $\begin{array}{l}\text { Ratio } \\
\text { of Diff. }\end{array}$ \\
\hline 1 & WC (Test 4 to Test 1$)$ & 2.08 & 3.74 & 1.80 \\
\hline 2 & FC (Test 5 to Test 2) & 2.53 & 5.78 & 2.28 \\
\hline \multirow[t]{3}{*}{3} & $\begin{array}{l}\text { FWC (Test } 6 \text { to Test } \\
\text { 3) }\end{array}$ & 4.30 & 7.92 & 1.84 \\
\hline & & \multicolumn{3}{|c|}{ Comparison of $S_{\mathrm{J}, \text { ini }}(\mathrm{kNm} / \mathrm{rad})$} \\
\hline & & $\begin{array}{l}2 \mathrm{~mm} \\
\text { cleat }\end{array}$ & $\begin{array}{l}6 \mathrm{~mm} \\
\text { cleat }\end{array}$ & $\begin{array}{l}\text { Ratio } \\
\text { of Diff. }\end{array}$ \\
\hline 4 & WC (Test 4 to Test 1$)$ & 91 & 179 & 1.97 \\
\hline 5 & FC (Test 5 to Test 2) & 153 & 195 & 1.27 \\
\hline 6 & $\begin{array}{l}\text { FWC (Test } 6 \text { to Test } \\
\text { 3) }\end{array}$ & 186 & 383 & 2.06 \\
\hline
\end{tabular}
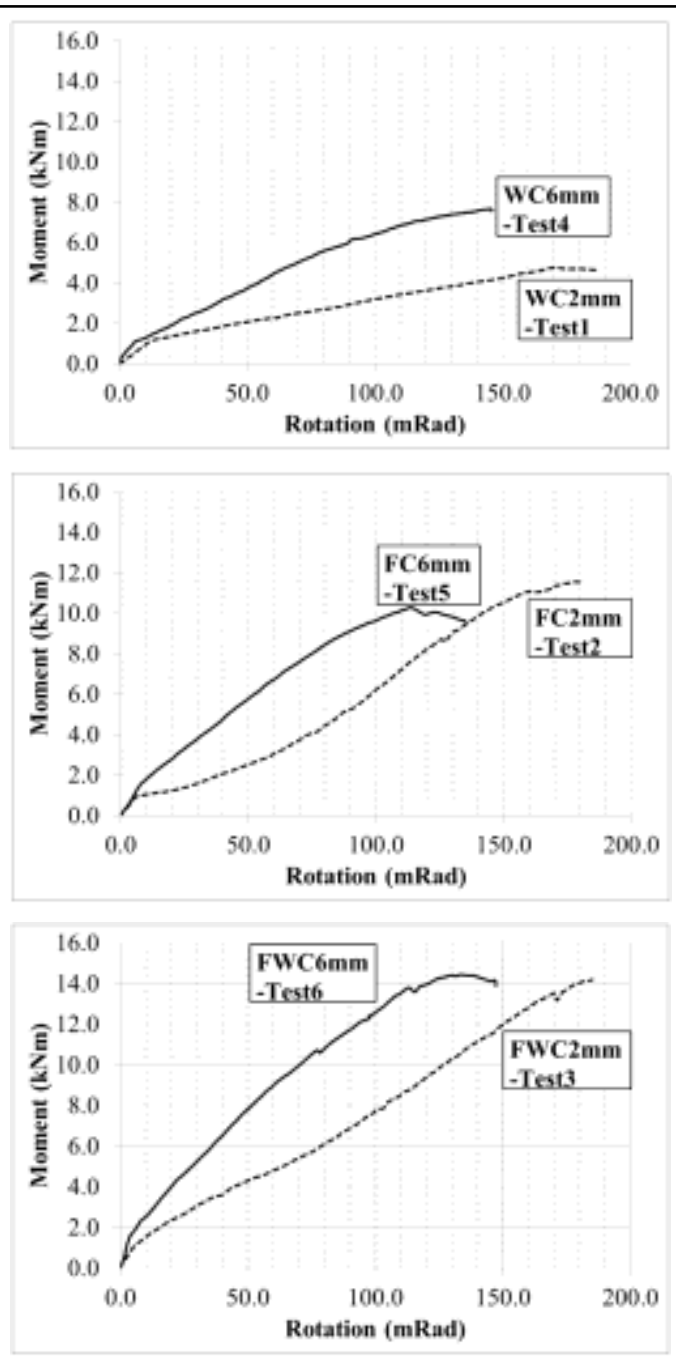

Figure 3. Moment rotation behavior of the tested joints 


\section{Conclusion}

Laboratory investigations on full-scaled isolated joint with three bolted angle configurations were successfully carried out. All specimens failed due to loss of joint strength and stiffness, leading to beam's excessive deflection. By increasing the angle-cleat size from $2 \mathrm{~mm}$ to $6 \mathrm{~mm}$, the moment resistance was found to increase in the range of 1.80 to 2.28. The ratio of difference for rotational stiffness increased in the range of 1.27 to 2.06. This work was limited by the number of test and joint configurations. It is recommended that numerical investigation should be carried out to study a wider range of bolted angle joints to comprehend joints behavior in cold-formed steel frames.

\section{Acknowledgment}

This work was financially supported by the Ministry of Education Malaysia and Universiti Teknologi Malaysia (UTM grant number 4F658and 4F647). The experimental work was carried out in Structures and Materials Laboratory, Faculty of Civil Engineering, UTM. The technical and financial assistance are gratefully acknowledged.

\section{References}

[1] Mohamed M. N. Research and Development (R\&D) for IBS. Buletin Bulanan Jurutera Bil 2003 No 6. Institute of Engineers, Malaysia. 2003.

[2] Mottram, J.T. \& Zheng, Y. Further tests on beam-to-column connections for pultruded frames: flange-cleated. Journal of Composites for Construction. 3(3): 108-116. 1999.

[3] Pucinotti, R. Top-and-seat and web angle connections: prediction via mechanical model. Journal of Constructional Steel Research. 57: 661694. 2001.

[4] Chung, K.F. \& Lawson, R.M. Structural performance of shear resisting connections between cold-formed steel sections using web cleats of cold-formed steel strip. Engineering Structures. 22: 1350-1366. 2000.

[5] Tan C.S., Tahir M. M. Tahir, Shek P.N, Mohammad S, Kueh A.B.H. Structural Behaviour of Combined Flange-cleat and Gusset Plate Connection for Cold-formed Steel Double Channel Sections. Advanced Science Letters Vol. 14. 517-520. 2012.

[6] Tan C.S., Tahir M. M. Tahir, Shek P.N, Mohammad S, Kueh A.B.H. Experimental Investigation on Slip-in Connection for Cold-formed Steel Double Channel Sections. Advanced Materials Research Vols. 250-253: 1038-1041. 2011.

[7] Tan C.S., Tahir M. M. Tahir, Shek P.N. Experimental Investigation on Bolted Angle Connections for Cold-Formed Steel Sections. In: (Lau H.H. (Ed.)) Advances in Steel and Aluminium Structures. Singapore: Research Publishing. 186-192. 2011.

[8] Jaspart, J. P. Structural Connections: Experimentation as design Tool. Seminar Structural Assessment: The Role of Large and Full Scale Testing. City University, London. July. 1996.

[9] Bose, B and Hughes, A.F. Verifying the performance of standard ductile connections for semi-continuous steel frames. Structural and Building. 110: 441-457. 1995.

[10] Prinz G.S, Nussbaumer A., Borges L., Shyam Khadka. Experimental testing and simulation of bolted beam-column connections having thick extended endplates and multiple bolts per row. Engineering Structures. 59: 434-447. 2014.
[11] Markazi, F.D., Beale, R.G. and Godley, M.H.R. Experimental Analysis of Semi-Rigid Boltless Connectors. Thin-Walled Structures. 28(1): 5787. 1997.

[12] Chung, K.F. \& Lau, L. Experimental investigation on bolted moment connections among cold-formed steel members. Engineering Structures. 21: 898-911. 1999.

[13] Wong, M.F. \& Chung, K.F. Structural behaviour of bolted moment connections in cold-formed steel beam-column sub-frames. Journal of Constructional Steel Research. 58: 253-274. 2002.

[14] Tahir M.M., Tan C.S. Experimental Tests on Partial Strength Connection for Cold-formed Steel Double Lipped Channel Sections. Fifth International Conference on Thin-Walled Structures. Brisbane, Australia, 2008.

[15] Tan Cher Siang. Behaviour of Pin and Partial Strength Beam-to-column Connections with Double Channel Cold-formed Steel Sections. Thesis, Universiti Teknologi Malaysia, 2009.

About Author (s):

\begin{tabular}{|l|l|}
\hline & $\begin{array}{l}\text { Dr. Cher Siang Tan is a senior lecturer } \\
\text { in Faculty of Civil Engineering, } \\
\text { Universiti Teknologi Malaysia(UTM). } \\
\text { His research interest is in cold-formed } \\
\text { steel, lightweight structures and } \\
\text { materials. }\end{array}$ \\
\hline $\begin{array}{l}\text { Professor Ir Dr Mahmood Md Tahir is } \\
\text { the director of UTM Construction } \\
\text { Research Centre, Universiti Teknologi } \\
\text { Malaysia(UTM).. He is actively } \\
\text { research on steelwork joints, composite } \\
\text { structures and interlock brick system. }\end{array}$ \\
$\begin{array}{l}\text { Mustapha Muhammad Lawan } \\
\text { Ph.D student at UTM Construction } \\
\text { Research Centre, UTM, Johor Bahru, } \\
\text { Johor, Malaysia }\end{array}$ \\
\hline
\end{tabular}

